\title{
RESVERATROL VE DIALIL DISÜLFITIN SIÇAN TESTISINDE KADMIYUM ILE OLUŞTURULMUŞ AKUT HASARA ETKISI
}

\author{
EFFECTS OF RESVERATROL AND DIALLYL DISULFIDE ON CADMIUM INDUCED \\ ACUTE RAT TESTIS DAMAGE
}

\author{
Kıymet Z. HALK ${ }^{1}$, Zeynep KAHVECi², İlkin ÇAVUŞOĞLU², Şahin A. SIRMALI ${ }^{3}$ \\ ${ }^{1}$ Uludağ Üniversitesi, Sağlık Bilimleri Enstitüsü, Histoloji ve Embriyoloji Anabilim Dalı, Bursa. \\ Uludağ Üniversitesi, Tıp Fakültesi, Histoloji ve Embriyoloji Anabilim Dalı, Bursa. \\ ${ }^{3}$ SANKO Üniversitesi, Tıp Fakültesi, Histoloji ve Embriyoloji Anabilim Dalı, Gaziantep.
}

\begin{abstract}
Cite this article as: Halk KZ, Kahveci Z, Çavuşoğlu I, Sırmalı ŞA. Effects of Resveratrol and Diallyl Disulfide on Cadmium Induced Acute Rat Testis Damage. Med J SDU 2020; 27(3): 273-282.
\end{abstract}

Öz

\section{Amaç}

Önemli bir çevre kirletici ve dokular üzerine zararlı etkileri olan kadmiyumun erkek fertilitesi üzerine oluşturduğu hasara karşı resveratrolün ve dialil disülfitin koruyucu etkilerinin araştııılmasıdır.

\section{Gereç ve Yöntem}

Yapılan deneyde Wistar albino cinsi erkek sıçan kullanıldı ve 5 grup (A: kontrol, B1: $\mathrm{CdCl}$, B2: RES + $\mathrm{CdCl}_{2}$, B3: DDS $\left.+\mathrm{CdCl}_{2}, \mathrm{~B} 4: \mathrm{RES}+\mathrm{DDS}+\mathrm{CdCl}_{2}\right)$ oluşturuldu. Histolojik değişiklikleri değerlendirmek için testis dokuları, Hematoksilen ve Eozin ile boyandı ve Modifiye Johnsen skorlaması yapıldı. Gruplarda gözlenen apoptoz, TUNEL yöntemi ve aktif kaspaz-3 immünohistokimyasal boyama yöntemi ile değerlendirildi.

\section{Bulgular}

B1 grubunda, kadmiyumun seminifer tübüllerde hasara yol açtığı, spermatogenezi durdurduğu ve germ hürcelerinde apoptozu indüklediği gözlendi. Modifiye Johnsen skorlama sonuçlarında kontrole göre B1 grubunda anlamlı derecede azalma, apoptotik indeks sonuçlarında ise anlamlı derecede artış görüldü. B1 grubuyla B2, B3 ve B4 grupları karşılaştırıldığında;
Modifiye Johnsen skorlama sonuçlarında B1 ile B2 grubu arasında anlamlı bir farklılık görülmezken, B3 ve B4 gruplarında anlamlı artış görüldü. Ayrıca apoptotik indeks sonuçlarında B2 grubunda anlamlı bir farklılık görülmezken, B3 ve B4 gruplarında anlamlı azalma görüldü $(p<00,1)$.

\section{Sonuç}

Sıçan testisinde kadmiyum ile oluşturulan akut hasarın baskılanmasında resveratrol ve dialil disülfitin rolüne yönelik bilgiler ortaya konuldu. Belirlediğimiz dozda resveratrol bu akut hasarın baskılanmasında etkili olmazken dialil disülfit ve resveratrol ile birlikte kullanımı hasarı önlemede etkili bulundu. Literatür analizimize göre bu çalışma kadmiyumun indüklediği testis hasarına karşı dialil disülfitin koruyucu etkilerinin gösterildiği ilk çalışmadır.

Anahtar Kelimeler: Kadmiyum, resveratrol, dialil disülfit, sıçan testis hasarı, apoptoz.

\section{Abstract}

\section{Objective}

In this study, the protective effects of resveratrol and diallyl disulfide against to damage of cadmium, which is a major environmental pollutant and has harmful

İletişim kurulacak yazar/Corresponding author: halk.zulal@gmail.com

Müracaat tarihi/Application Date: 02.05.2019 • Kabul tarihi/Accepted Date: 28.06.2019

ORCID IDs of the authors: K. Z. H. 0000-0002-8226-221X; Z. K. 0000-0001-6189-4296;

i. Ç. 0000-0003-3106-5467; Ş. A. S. 0000-0003-1981-9131 
effects on tissues, on male fertility were investigated.

\section{Materials and Methods}

In the experiment, Wistar albino male rats were used and 5 groups (A: control, B1: $\mathrm{CdCl} 2, \mathrm{~B} 2: \mathrm{RES}+\mathrm{CdCl}_{2}$, B3: DDS + $\mathrm{CdCl}_{2}$, B4: RES + DDS + $\mathrm{CdCl}_{2}$ ) were formed. Testicular tissues were stained with Hematoxylin and Eosin and Modified Johnsen scoring were performed to evaluate histologic changes. Apoptosis in the groups was evaluated with TUNEL method and active caspase- 3 immunohistochemistry.

\section{Results}

According to our findings, in group B1, cadmium caused damage in seminiferous tubules, have stopped spermatogenesis, and induced apoptosis in germ celIs. In the modified Johnsen scoring results, there was a significant decrease in the B1 group and a significant increase in the apoptotic index results. When B1 and B2, B3 and B4 groups were compared; While the- re was no significant difference between B1 and B2 groups in the modified Johnsen scoring results, there was a significant increase in B3 and B4 groups. In addition, there was no significant difference in the B2 group in apoptotic index results, but a significant decrease was observed in B3 and B4 groups $(p<00,1)$.

\section{Conclusion}

In conclusion, the role of resveratrol and diallyl disulfide in suppressing cadmium-induced acute damage in rat testis was demonstrated. While resveratrol is not effective in suppressing this acute damage, DialIyl disulfide and diallyl disulfide with resveratrol were found to be effective in preventing of damage. According to our literature analysis, this study is the first study showing the protective effects of diallyl disulfide against cadmium-induced testicular damage.

Keywords: Cadmium, resveratrol, diallyl disulfide, rat testis damage, apoptosis.

\section{Giriş}

Kadmiyum (Cd), birçok endüstriyel süreç ile ilişkili önemli bir toksik maddedir. Vücutta yavaş yavaş biriken bu ağır metale mesleki maruziyet genellikle pillerin, pigmentlerin imalatı sırasında veya maden ocaklarında meydana gelirken, genel nüfus atmosferden inhalasyonla veya kontamine olmuş içme suları ve yiyecekler yoluyla maruz kalır $(1,2)$. Sigarada yüksek miktarda bulunması (3), endüstriyel alanda yaygın kullanımı ve buna bağlı olarak meslek hastalıklarına neden olmasından dolayı Cd yaygın olarak toksik etkileri çalışılan bir metaldir.

Serbest radikallerin oluşumuna bağlı olarak oluşan oksidatif stres, Cd'nin oluşturduğu toksisitenin ana nedenidir. Serbest oksijen radikalleri lipit peroksidasyonunu uyararak hücre membran yapılarını bozar ve lipit peroksidasyonunun erkeklerde infertilite ve sperm fonksiyon bozukluğunda kilit rolü vardır. Antioksidanlar, serbest radikal oluşumunu önleyen ve mevcut radikallerle reaksiyona girerek daha zararlı formlara dönüşmelerini engelleyen bileşiklerdir (4-6).

Resveratrol (RES), patojenik bir saldırı, morötesi ışıma gibi yaralanmalara veya strese yanıt olarak bitkilerde doğal olarak üretilen bir polifenolik fitoaleksindir. Üzüm, fıstık, çilek, yer fıstığı, ladin, dut ve kurutulmuş köklerinde bulunan bu bileşik, bitkilerde enfeksiyon gelişimini inhibe eder (7). İnsanlarda, antioksidan, anti-inflamatuar, antikarsinojenik, antidiyabetik, kardiyoprotektif ve antiagening özellikleri nedeniyle birçok yararlı etkiye sahiptir $(8,9)$.
Dialil disülfit (DDS), sarımsakta bulunan yağda çözünen organosülfür bileşiklerdendir. Güçlü bir antioksidan kapasiteye sahiptir (10). Ürotoksisite, genotoksisite, nefrotoksisite, hepatoksisite üzerine güçlü protektif etkileri bildirilmiştir (11-14). Medikal alanda yaygın kullanılmasına rağmen ağır metal toksisitesi üzerine olan etkileri ile ilgili sınırlı bilgi bulunmaktadır (15).

Bu çalışmada, özellikle endüstriyel alanda çalışan işçilerin sıklıkla maruz kaldığı kadmiyum toksisitesinin erkek fertilitesi üzerine oluşturduğu hasarın önlenmesi ya da bu toksisitenin etkilerinin en aza indirgenmesi için bir koruma yöntemi bulmak amaçlanmıştır. Bu amaçla önemli antioksidan maddelerden RES, DDS ve bunların kombinasyonunun sıçan testisinde oluşturulan akut kadmiyum toksisitesi üzerindeki hasar önleyici etkisi incelenmiştir.

\section{Gereç ve Yöntem}

\section{Kimyasallar}

Yapılan deneyde $\mathrm{Cd}$ toksisitesi oluşturmak amacıyla Cd'un suda çözülen formu kadmiyum klorür $\left(\mathrm{CdCl}_{2}\right)$ kullanıldı. $\mathrm{CdCl}_{2}$ (Sigma-Aldrich: 202908); serum fizyolojik (SF) içerisinde çözülerek intraperitoneal (i.p) enjeksiyon ile, resveratrol (RES, Sigma-Aldrich: R5010); SF içerisinde çözülerek oral gavaj (16) ile ve dialil disülfit (DDS, Sigma-Aldrich: 317691); mısır yağı (14) içerisinde çözülerek i.p. enjeksiyon (17) ile uygulandı. 


\section{Deney Hayvanları}

Bu çalışma Uludağ Üniversitesi Hayvan Deneyleri Yerel Etik Kurulu (HADYEK)'nun 26.05.2015 tarih ve 2015-07/05 sayılı kararı ile etik yönden uygun bulunarak yapılmıştır. Çalışmaya 35 adet, Wistar albino cinsi erişkin erkek sıçan alındı. Deneyler süresince sıçanlar, 12 saat aydınlık 12 saat karanlık ortamda, her bir kafeste en fazla 4 adet sıçan olmak koşuluyla barındırılarak, serbestçe beslenmeleri ve su içmeleri sağlandı. Deney başlangıcında hayvanların vücut ağılıkları uygulanacak madde dozlarını belirlemek üzere tartıldı.

Grup A (kontrol grubu): Herhangi bir uygulamaya maruz kalmayan denekler $(n=7)$.

Grup B (deney grubu): Akut kadmiyum toksisitesi oluşturulan deneklerin yer aldığı gruplar.

Grup B1 $\left(\mathrm{CdCl}_{2}\right): 5$ gün boyunca SF ve mısır yağı, 6 . gün $1 \mathrm{mg} / \mathrm{kg} \mathrm{CdCl}_{2}(\mathrm{n}=7)$.

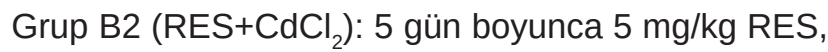
6. gün $1 \mathrm{mg} / \mathrm{kg} \mathrm{CdCl}(\mathrm{n}=7)$.

Grup B3 (DDS+CdCl $)$ : 5 gün boyunca $50 \mathrm{mg} / \mathrm{kg}$ DDS, 6. gün $1 \mathrm{mg} / \mathrm{kg} \mathrm{CdCl}(\mathrm{n}=7)$.

Grup B4 (RES+DDS+CdCl $)$ : 5 gün boyunca $5 \mathrm{mg} / \mathrm{kg}$ RES ve $50 \mathrm{mg} / \mathrm{kg}$ DDS, 6. gün $1 \mathrm{mg} / \mathrm{kg} \mathrm{CdCl}{ }_{2}(\mathrm{n}=7)$.

Tüm denekler $\mathrm{CdCl}_{2}$ uygulamasından 48 saat sonra vücut ağırlıkları kaydedilip, sakrifiye edildi. Çevre dokularından iyice temizlenen testislerin ağırlıkları tartılıp kayıt edildi ve ışık mikroskobik incelemeler için hazırlandı.

\section{Testis Ağırlık Indeksi Hesaplaması}

Deney hayvanlarına ait sağ ve sol testis ağırığı toplamı aşağıdaki formüle göre hesaplanarak her bir hayvan için testis ağırlık indeksi (TAi) aşağıdaki formüle göre hesaplandı;

TAi: [(sağ+sol testis ağırlıkları toplamı)/vücut ağırlığı] $\times 100$

\section{Morfolojik Değerlendirme}

Testis dokuları \%10'luk formalin ile immersiyon fiksasyonundan sonra rutin doku takibine alındı ve parafin bloklara gömüldü. Parafin bloklardan $5 \mu \mathrm{m}$ kalınlığında alınan kesitler, genel morfolojik değerlendirme ve kantitatif analiz yapabilmek için Hematoksilin-Eosin (H\&E) ile boyandı. Spermatogenezi değerlendirmek amacıyla Modifiye Johnsen skorlama sistemi kullanıldı (18) (Tablo 1).

\section{Seminifer Tübüllerde Apoptozun Değerlendirilmesi} Apoptoz tayini için TUNEL yöntemi ile kaspaz-3 immünohistokimyasal boyama yöntemi kullanıldı. Parafin bloklardan alınan $5 \mu \mathrm{m}$ kalınlığındaki seri kesitler poly-Llysne ile kaplı lamlar üzerine alındı. TUNEL için In Situ Hücre Ölüm Tespit Kiti kullanıldı ve boyama protokolü üretici firma tarafından önerilen şekilde gerçekleştirildi (Roche, In Situ Apoptosis Detection Peroksidase kit, POD, Ref: 11684817910, USA). TUNEL boyamasında gösterilen apoptotik hücrelerin varlığı doğrulamak amacıyla seri kesitlere yapılan kaspas-3 immünohistokimyasal boyama, avidin biyotin- peroksidaz yöntemi (ABC Metodu) ile gerçekleştirildi. Primer antikor olarak kaspaz-3 monoklonal immünglobulin G (IgG), (1:200 dilüsyon, 2 gece inkübasyon), (Cellsignaling, Cleaved Caspase-3 (Asp175)(5A1E) Rabbit mAb) kullanıldı.

\begin{tabular}{|c|l|}
\hline Skor & Modifiye Johnsen Skorlaması \\
\hline 10 & Tam spermatogenez ve tam tübül \\
\hline 9 & Seminifer epitel mevcut ama dağınık, birçok geç spermatid \\
\hline 8 & Sadece birkaç geç spermatid \\
\hline 7 & Hiç geç spermatid yok ancak birçok erken spermatid \\
\hline 6 & Birkaç erken spermatid, spermatogenezin spermatid aşamasında durması \\
\hline 5 & Hiç spermatid yok, birçok spermatositler \\
\hline 4 & Birkaç spermatosit, spermatogenezin primer spermatosit aşamasında durması \\
\hline 3 & Sadece spermatogonyum \\
\hline 2 & Hiç germ hücresi yok, yalnızca sertoli hücreleri \\
\hline 1 & Hiç germ hücresi veya Sertoli hücresi yok \\
\hline
\end{tabular}


Her iki teknikte de Apoptotik indeks (AI) aynı şekilde ve aşağıda belirtilen formülle hesaplandı. Her kesitten 10 adet yuvarlak şekilli seminifer tübül rastgele seçildi. Seminifer tübüldeki pozitif işaretlenen hücrelerin sayısı tübüldeki tüm hücrelerin toplam sayısına bölündü ve sonuç 100 ile çarpıldı. (AI = TUNEL (kaspaz-3) pozitif hücre / toplam hücre x 100) (19).

\section{İstatiksel Analiz}

Sayısal verilerin istatistiksel analizi SPSS (Statistical Package for the Social Sciences, version 13.1, SSPS Inc., Chicago, IL, USA) (SPSS) programı kullanılarak yapıldı. Her bir gruba ait sayısal veriler ortalama \pm standart sapma (SS) olarak verilerek Kruskal Wallis varyans analizi (ikili karşılaştırmalar Mann-Whitney $U$ testi) ile karşılaştırıldı ve karşılaştırmalarda $p<0.05$ değeri anlamlı kabul edildi.

\section{Bulgular}

\section{Vücut Ağırlığı Farkı}

Tüm deney gruplarının deney öncesi vücut ağırlıkları ile deney sonrası vücut ağırlıkları tartıldı ve farkları hesaplandı. Vücut ağırlığı farkları istatiksel olarak karşılaştırıldığında gruplara arasında anlamlı bir fark saptanmadı. Tüm gruplarda deneklerin ağırlık kaybettiği görüldü. Gruplara göre vücut ağırlığı farkları ortalama (ort) ve standart sapma (SS) değerleri tablo 2'de verildi.

\section{Testis Ağırlık İndeksi}

Gruplara göre TAi indekslerine ait ortalama ve standart sapma değerleri tablo 3' da verildi. TAi değerlerinin istatiksel karşılaştırmalarında (Kruskal Wallis testine göre) gruplar arasında anlamlı fark saptanmadı.

\section{Işık Mikroskobik Bulgular}

Işık mikroskobik olarak kontrol ve deney gruplarını oluşturan sıçan testislerinde genel görünümü saptamak için H\&E ile boyanan kesitler değerlendirildi. Buna göre, A (kontrol) grubuna ait testis dokusu örneklerinde yapılan incelemelerde, tüm yapılar normal görünümündeydi (Şekil 1.a).

$\mathrm{B} 1\left(\mathrm{CdCl}_{2}\right)$ grubuna ait testis dokusu örneklerinin ışık mikroskobik incelemelerinde ise dejenerasyon oldukça belirgindi. Bu grupta testis dokusunda seminifer tübüllerde düzensizlik ile vakuolizasyon vardı ve spermatogenik hücre katmanında azalma olduğu dikkati çekti. Pek çok tübülde de hücreler arası ve hücre bazal membran arası bağlantı komplekslerinin dejenerasyonuna bağlı olarak spermatogenik hücre serilerinin tübül duvarından ayrıldığı ve lümene döküldüğü görüldü. Tübül duvarında spermatogenezin hiç bir evresi ayırt edilemiyordu. Ayrıca interstisyel ödeme bağlı olarak birbirlerinden uzaklaşmış seminifer tübüller, bağ dokusunda azalma ve damarlarda konjesyon gözlendi (Şekil 1.b).

\section{Tablo 2 Gruplara göre vücut ağırlıkları farkı ortalama ve standart sapma değerleri}

\begin{tabular}{|l|l|}
\hline Gruplar & Ort $\pm S S$ \\
\hline A (kontrol) & $24,3333 \pm 5,07718$ \\
\hline B1 $\left(\mathrm{CdCl}{ }_{2}\right)$ & $21,2857 \pm 6,66803$ \\
\hline B2 $\left(\right.$ RES $\left.+\mathrm{CdCl}_{2}\right)$ & $30,1429 \pm 7,51008$ \\
\hline B3 $\left(\mathrm{DDS}+\mathrm{CdCl}_{2}\right)$ & $39,2857 \pm 4,16170$ \\
\hline B4 (RES+DDS $\left.+\mathrm{CdCl}_{2}\right)$ & $20,2857 \pm 5,79702$ \\
\hline
\end{tabular}

\begin{tabular}{|c|c|}
\hline Gruplar & OrttsS \\
\hline A (kontrol) & $1,1133 \pm 0,04490$ \\
\hline $\mathrm{B} 1\left(\mathrm{CdCl}_{2}\right)$ & $1,1327 \pm 0,06187$ \\
\hline $\mathrm{B} 2\left(\mathrm{RES}+\mathrm{CdCl}_{2}\right)$ & $1,1678 \pm 0,05810$ \\
\hline $\mathrm{B} 3\left(\mathrm{DDS}+\mathrm{CdCl}_{2}\right)$ & $1,2970 \pm 0,04389$ \\
\hline $\mathrm{B} 4\left(\mathrm{RES}+\mathrm{DDS}+\mathrm{CdCl}_{2}\right)$ & $1,3440 \pm 0,08740$ \\
\hline
\end{tabular}


B2 (RES+C $\mathrm{CdCl}_{2}$ ) grubuna ait testis dokusu örneklerinden elde edilen bulgular sadece kadmiyum uygulanan grubla eşdeşti. İntersitisyel alanda yoğun ödem ve inflamasyon vardı. Kan damarlarında konjesyon ve dağılmalar görüldü. Ayrıca intersitisyel alanda Leydig hücreleri seçilemiyordu. Seminifer tübüllerde ödem vardı ve bazı tübüller de atrofikti. Germ hücre serisinin dağınık olduğu, bazal membrandan ayrıldığı ve lümene döküldüğü görüldü (Şekil 1.c).

B3 (DDS $+\mathrm{CdCl}_{2}$ ) grubana ait testis dokusu örneklerinin incelemelerinde, seminifer tübül duvarlarında hafif vakuolizasyon görülmekteydi fakat lümene dökülmüş germ hücreleri yoktu. Ayrıca düzgün bir spermatogenez, belirgin spermatogonyumlar ve diğer spermatogenetik seri hücreleri seçilebiliyordu. Intersisyel alanda Leydig hücreleri belirgin ve kan damarları normal durumdaydı (Şekil 1.d).
B4 (RES+DDS+CdCl $)$ grubu testis doku örnekleri incelemelerinde, gerek bazal membran ve gerekse seminifer tübül yapıları kontrol grubu ile eşdeşti. Düzgün seminifer tübül yapısı, interstisyel alanda belirgin Leydig hücreleri ve normal kan damarları gözlendi. Spermatogenezin normal olduğu ve spermatozoa üretiminin de devam ettiği görüldü (Şekil 1.e).

\section{Modifiye Johnsen Skorlama Değerlendirmesi}

Seminifer tübüllerde ki spermatogenez Modifiye Johnsen skoruna (Erdemir ve ark., 2012) göre değerlendirildi. Kontrol grubuyla $\mathrm{B} 1\left(\mathrm{CdCl}_{2}\right)$ karşılaştırıldığında Modifiye Johnsen skorunun anlamlı ölçüde azaldığı

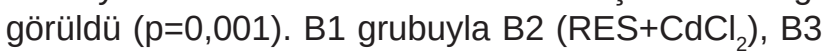
$\left(\mathrm{DDS}+\mathrm{CdCl}_{2}\right)$ ve $\mathrm{B} 4\left(\mathrm{RES}+\mathrm{DDS}+\mathrm{CdCl}_{2}\right)$ grupları karşılaştırıldı ve B2 (RES+CdCl${ }_{2}$ ) grubunda anlamlı bir değişim görülmezken ( $p=0,073)$, $B 3\left(D D S+C \mathrm{CCl}_{2}\right)$ ve B4 (RES+DDS+CdCl ) gruplarında anlamlı artış görüldü (sırasıyla, $p=0,011$ ve $p=0,001$ ) (Şekil.1.f).
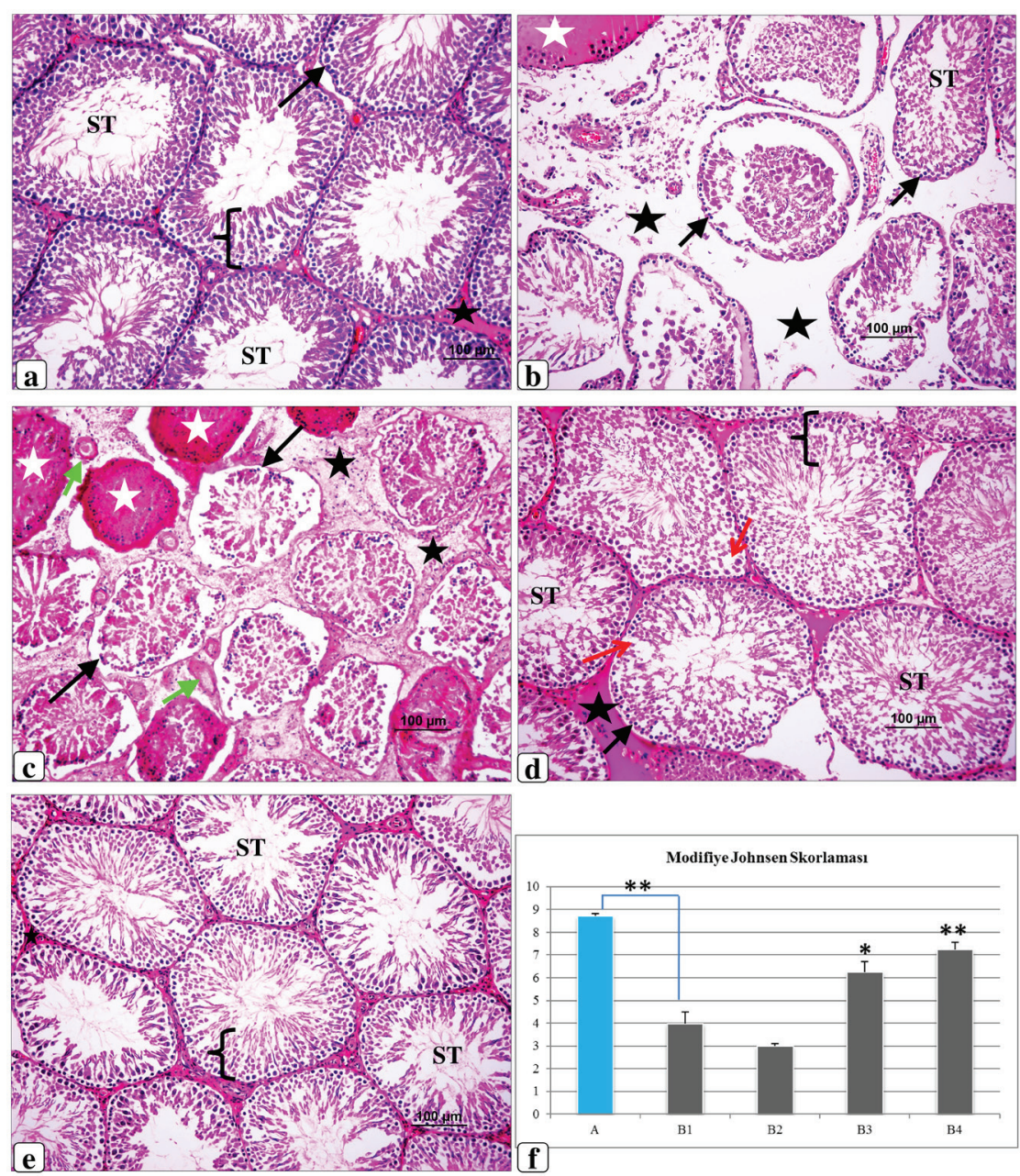

Şekil 1

Gruplara ait testis dokusunun histolojik değerlendirilmesi

a) A (Kontrol) grubu, b) B1 ( $\mathrm{CdCl}_{2}$ ) grubu, c) B2 (RES+ $\left.\mathrm{CdCl}_{2}\right)$ grubu, d) B3 (DDS+ $\left.\mathrm{CdCl}_{2}\right)$ grubu,

e) B4 (RES+DDS+CdCl $)$ grubu. ST: Seminifer tübüller; siyah yıldızlar: interstisyel alan; beyaz yıldız: ödemli seminifer tübüller; siyah parantez: germ hücre serisi; siyah ok: spermatogonyumlar; yeşil ok: kan damarları; kırmızı ok: vakuoller 20x büyütme ve H\&E boyama. f) Modifiye Johnsen skorlaması grafiksel gösterimi. * $p<0.05$, ${ }^{*} p<0.001$. 


\section{Apoptozun Değerlendirilmesi}

Çalışmamızda, apoptozun varlığını ortaya koymak için her gruba ait testis doku kesitlerine TUNEL boyaması ve TUNEL boyamasında gösterilen apoptotik hücrelerin varlığını doğrulamak amacıyla kaspaz-3 immünohistokimyasal boyama yöntemi uygulandı. Kontrol grubuna ait testis dokularında apoptoz özellikle spermatogonyumlarda, $\mathrm{B} 1\left(\mathrm{CdCl}_{2}\right)$ ve $\mathrm{B} 2(\mathrm{RES}+\mathrm{C}-$ $\mathrm{dCl}_{2}$ ) grubu testis dokularında ise çoğu spermatogonyum, spermatid ve Leydig hücrelerinde gözlendi. B3 $\left(\mathrm{DDS}+\mathrm{CdCl}_{2}\right)$ ve $\mathrm{B} 4\left(\mathrm{RES}+\mathrm{DDS}+\mathrm{CdCl}_{2}\right)$ gruplarında apoptoz kontrol grubuna benzerdi. Tüm gruplarda kaspaz-3 immünohistokimya bulguları ile TUNEL bulguları paralellik gösterdi (Şekil.2).

Gruplara göre seminifer tübüllerdeki TUNEL pozi- tif ve kaspaz-3 pozitif işaretlenen hücrelerin yüzdesi hesaplandı. Kontrol grubuyla B1 karşılaştırıldığında Al'nın anlamlı ölçüde arttığı görüldü $(p=0,001)$. B1 $\left(\mathrm{CdCl}_{2}\right)$ grubuyla B2 $\left(\mathrm{RES}+\mathrm{CdCl}_{2}\right), \mathrm{B} 3\left(\mathrm{DDS}+\mathrm{CdCl}_{2}\right)$ ve B4 (RES+DDS+CdCl2) grupları karşılaştırdı ve $B 2$ $\left(\mathrm{RES}+\mathrm{CdCl}_{2}\right.$ ) grubunda anlamlı bir değişim görülmezken $(p=0,106)$, B3 ve B4 gruplarında anlamlı azalma görüldü (sırasıyla, $p=0,001$ ve $p=0,001$ ). Tüm gruplarda kaspaz-3 immünohistokimya bulguları ile TUNEL bulguları paralellik gösterdi (Şekil.3). Kontrol grubuyla B1 karşılaştırıldığında kaspaz-3 hesaplamasının anlamlı ölçüde arttığı görüldü $(p=0,03)$. B1 grubuyla B2, $B 3$ ve B4 grupları karşılaştırdı ve B2 grubunda anlamIı bir değişim görülmezken ( $p=0,181)$, B3 ve B4 gruplarında anlamlı azalma görüldü (sırasıyla, $p=0,001$ ve $p=0,001)$.

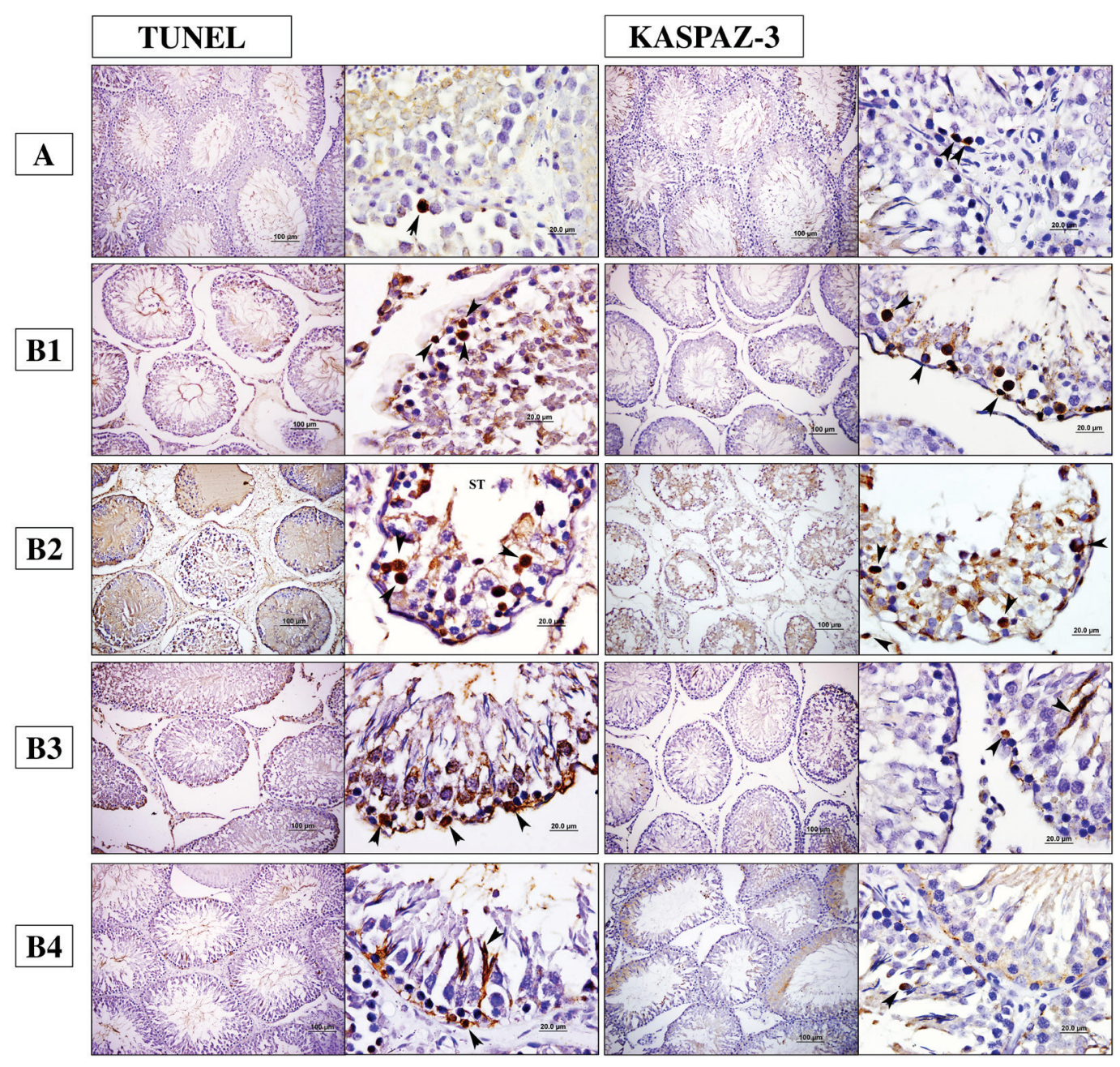

Şekil 2

Gruplara ait TUNEL ve kaspaz-3 immünohistokimyasal boyaması

Siyah ok başları: pozitif işaretlenen hücreler. 

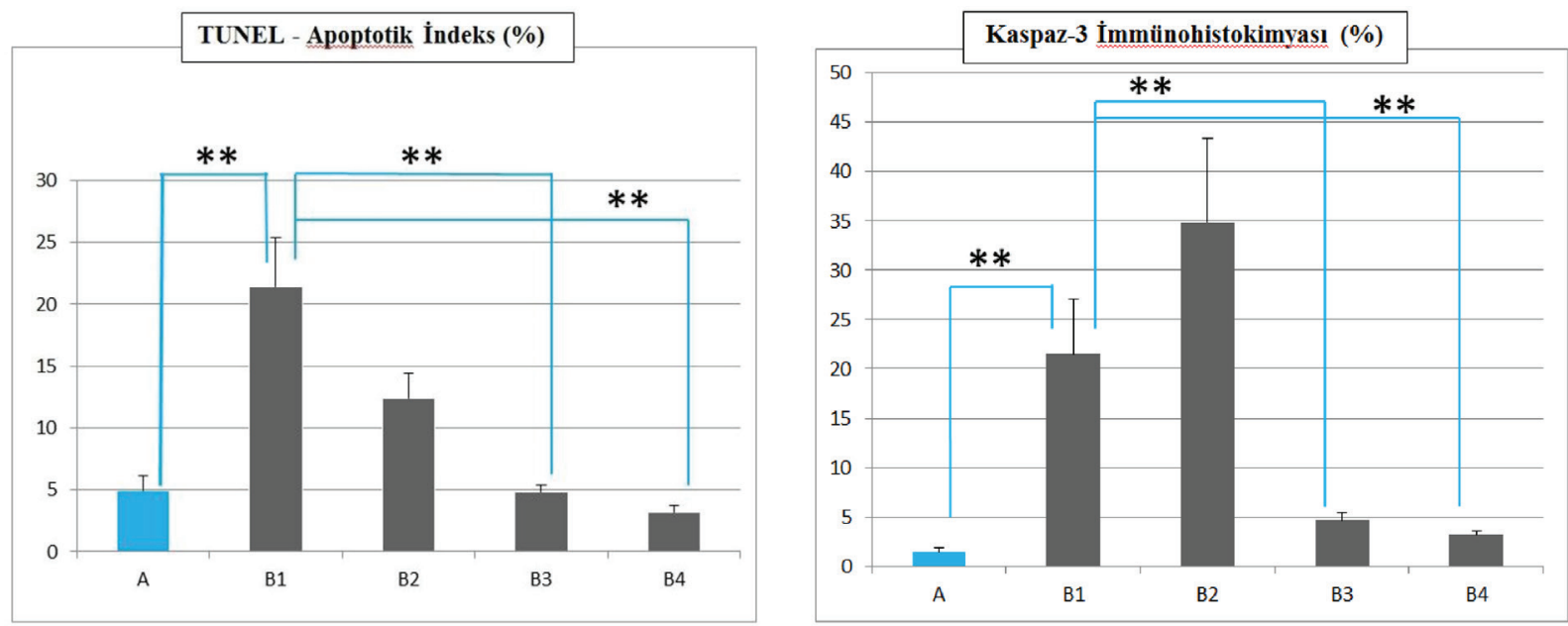

Şekil 3

TUNEL ve kaspaz-3 hesaplaması grafiksel gösterimi

A (kontrol), B1 $\left(\mathrm{CdCl}_{2}\right), \mathrm{B} 2\left(\mathrm{RES}+\mathrm{CdCl}_{2}\right), \mathrm{B} 3\left(\mathrm{DDS}+\mathrm{CdCl}_{2}\right), \mathrm{B} 4\left(\mathrm{RES}+\mathrm{DDS}+\mathrm{CdCl}_{2}\right) .{ }^{*} \mathrm{p}<0.05,{ }^{*} \mathrm{p}<0.001$.

\section{Tartışma}

Çalışmamızda, kadmiyumun erkek fertilitesi üzerine oluşturduğu hasar araştırılmış ve önemli antioksidan maddelerden resveratrol, dialil disülfit ve bunların kombinasyonlarının bu hasarı ne derece ve ne yönde etkilediği belirlenmeye çalışılmıştır. Bu çalışma kapsamında elde edilen verilerden öncelikle A grubu ile B1 grubunun sonuçları karşılaştırılarak verilen kadmiyumun hasar oluşturup oluşturmadığı saptanmış, ek olarak B1 grubu ile B2, B3 ve B4 grupları karşılaştırılarak uygulanan maddelerin etkileri araştırımıştır.

Kadmiyum özellikle çinkonun rafinasyonu esnasında ortaya çıkar (1). Damek-Poprawa ve Sawicka-Kapusta isimli araştırmacıların bir çelik fabrikası çevresinde ve çinko ergitme tesisi alanında yaptıkları bir saha çaış̧masında, ağır metallere (kadmiyum ve kurşun) maruz kalmış kemiricilerin dokularında bu ağır metallerin histopatolojik değişikliğe neden olduğu gösterilmiştir (20). Ağır metallerin organizmadaki metabolizması kemirgenler ve insan dokularında benzer olduğu için, analiz edilen çelik fabrikalarında olduğu gibi benzer sanayi bölgelerinde, çinko ergitme araçlarından yayılan emisyonların insan sağlığı için önemli bir tehdit oluşturduğu düşünülmektedir.

Birçok çalışma, kadmiyumun testiküler histopatolojide çeşitli değişikliklere neden olduğunu göstermiştir. Kadmiyum toksisitesi testislerde hızlıdır. İntraperitoneal veya subkutanöz enjeksiyon yoluyla verildiğinde, akut kadmiyum kaynaklı hasar testislerde kendini hemorajik inflamasyon, dejenerasyon ve organın bozulması, seminifer tübüllerde vakuolizasyon ile ken- dini gösterir $(21,22)$. Yüksek doz kadmiyumdan sonra seminifer tübülerin çapında belirgin bir azalma ve bununla birlikte tübüler hacim yoğunluğunun anlamlı olarak azaldığı bildirilmiştir (23). Ayrıca düşük dozlarda uzun süre $\mathrm{CdCl}_{2}$ alınımı sıçan testisinde belirgin morfolojik veya proliferatif değişiklikler olmadan germinal epitelin apoptotik indeksini ve hücrelerde kaspaz-3 ekspresyonunu artırdığı rapor edilmiştir $(24,25)$.

TUNEL ve kaspaz-3 boyanma sonuçlarında, kontrol grubuna ait testis dokusu kesitlerinde TUNEL pozitif ve kaspaz-3 pozitif hücrelerin bulunması ve kontrol grubu apoptotik indeksi ortalamasının 4,8 olması spermatogenez sırasında kusurlu germ hücrelerinin yok edilmesi veya Sertoli hücreleri ile germ hücreleri arasında uygun sayısal oranın sağlanmasına yöneliktir. Spermatogenez sırasında apoptoz yaygın görülen bir durumdur (26).

Resveratrol başta üzüm olmak üzere pek çok bitki de stres faktörüne karşı yanıt olarak sentezlenen, fitoaleksin yapısında bir bileşiktir (27). Resveratrol önemli bir antioksidan (28), antikanserojen (29) ve anti-inflamatuvar (30)'dır ve ayrıca östrojen agonisti $(31,32)$ 'dir. Bunun yanı sıra azot oksit üretimini artırarak oksidatif stresten dokuyu koruyarak vazodilatör etki de göstermektedir (33-35).

Çalışmamızda, Palsamy ve Subramanian (2011)'nin çalışmasına benzer olarak resveratrolü oral ve $5 \mathrm{mg} /$ kg olacak şekilde uyguladık. Referans aldığımız bu çalışmada resveratrolün diyabetli sıçan böbreklerinde streptozotosin-nikotinamid ile indüklenen oksidatif stresi hafiflettiği, anti inflamatuar ve koruyucu etkiler 
gösterdiği rapor edilmiştir (16). Benzer doz kullanılan pek çok çalışma bulunmaktadır (36-39).

Deney gruplarımıza ait H\&E boyanan kesitler incelendiğinde $\mathrm{B} 2\left(\mathrm{RES}+\mathrm{CdCl}_{2}\right)$ grubunda, $\mathrm{B} 1\left(\mathrm{CdCl}_{2}\right)$ grubuna benzer olarak yoğun ödem, kan damarlarında konjesyon ve dağılmalar görüldü. Seminifer tübüllerde ödem vardı ve bazı tübüller de atrofikti. Germ hücre serisinin dağınık olduğu, bazal membrandan ayrıldığı ve lümene döküldüğü görüldü. Modifiye Johnsen skorlama bulguları B1 grubu ile B2 grubu arasında anlamlı bir fark olmadığını gösterdi. Ayrıca yoğun apoptoz gözlenen B2 grubunun apoptotik indeks ve kaspaz-3 değerlendirme sonuçları B1 grubu ile karşılaştırıldığında anlamlı bir farklılık görülmemiştir. Resveratrolün akut kadmiyum alımına karşı apoptotik etkiyi değiştiremediği gözlenmiştir.

2014 yılında Ranawat ve ark.'nın erkek Swiss albino farelerde yaptıkları çalışmada birçok önemli biyolojik fonksiyona sahip güçlü bir antioksidan olmasına rağmen resveratrolün, pro-oksidan gibi davranabildiği ve testis dokusunda hasar yaratan etkilere neden olduğu görülmüştür. Resveratrolün prooksidan yeteneği, testiküler histomorfolojideki değişiklikler dışında sperm motilitesini ve spermatozoon konsantrasyonunu düşürdüğünü ve resveratrol ile indüklenen ROS üretimindeki artışın, testiküler dokudaki lipit peroksidasyonunu arttırdığı, bu da doku morfolojisinde ve spermatogenezde değişikliğe neden olan ana etkenlerden biri olduğu bildirilmiştir (40).

Bizim çalışmamızda resveratrolün kadmiyum uygulaması ile birlikte böyle bir pro-oksidan etki göstermiş olabileceğini düşündürmüştür. İkinci olasılık resveratrolün beklenen koruyucu etkiyi gösterememesinin nedeni kadmiyum ile indüklenen testiküler hasara, belirlenen dozun yetersizliği olabilir. Üçüncü olasılık ise resveratrolün ve kadmiyumun sahip oldukları güçlü östrojen ve androjen benzeri özellikleri (41-44) nedeni ile henüz bilmediğimiz bir yolakla bu sonuca ulaşmamızı sağlaması olabilir.

Resveratrolün kanser hücrelerinde, proapoptotik Bax ve Bak ekspresyonunu arttırdığı ve antiapoptotik Bcl2 ve Bcl-xL'yi inhibe ettiği bildirilmiştir. İnsan meme kanseri hücrelerinde resveratrol, hücre proliferasyonunda azalma, aynı zamanda hücre ölüm oranlarının da artmasına neden olmuştur $(45,46)$. Seçici apoptoz indüksiyonunun, patolojik bozuklukların ve kanserin dönüşümü, ilerlemesinin önlenmesi için umut verici bir strateji olduğu araştırmacılar tarafından bildirilmiştir (47). Çalışmamızda da apoptotik indeks ve kaspaz-3 değerlendirme sonuçları, resveratrolün kadmiyum ile indüklenmiş hasarlı hücreleri seçici apoptoz indüksiyonu ile apoptoza yöneltmiş olabileceğini düşündürmüştür.

Kanser önleyici bir komponent olarak düşünülen sarımsak yağı 20'den fazla organosülfür bileşiği içerir. Bu bileşikler arasında, ikincil metabolitlerin önemli bir bileşenini oluşturan dialil disülfit; kanser, genotoksisite, nefrotoksisite ve ürotoksitenin önlenmesinde güçlü bir bileşiktir (11-14).

Lee ve ark. (2014)'nın karbon tetraklorürün $\left(\mathrm{CCl}_{4}\right)$ indüklediği oksidatif karaciğer hasarına karşı 5 gün oral olarak uygulanan $50 \mathrm{mg} / \mathrm{kg}$ dialil disülfitin; antioksidan enzimlerin ekspresyonunu arttırdığını ve aynı zamanda TUNEL pozitif ve kaspaz 3 pozitif hücre sayısını azalttığını bildirmişlerdir (48).

Dialil disülfitin sıçanlarda siklofosfamid ile indüklenen testiküler toksisiteye karşı koruyucu etkiye sahip olduğunu bildirilmiştir (10). Bu çalışma dialil disülfitin testiküler toksisite üzerine etkisinin araştıııldığı ve literatüre geçen tek çalışmadır. Ayrıca dialil disülfitnin ağır metal toksisitesi üzerine etkilerinin araştırıldığı çalışmalar oldukça sınırlıdır.

Bu çalışmalara paralel olarak bizim çalışmamızda da; B3 (DDS+ $\mathrm{CdCl}_{2}$ ) grubuna ait histolojik ve immünohistokimyasal bulgularımız uygulanan kadmiyuma karşı DDS'in koruyucu etkisi olduğunu göstermektedir. Kadmiyum ile birlikte DDS uygulanan sıçanların testis dokularındaki bazı tübüllerde epiteller arası vakuol oluşumu görülse bile seminifer tübüllerin büyük kısmı normal gözlenmiştir. B1 grubu ve B3 grubu Modifiye Johnsen skorlama sonuçları karşılaştırıldığında spermatogenezin anlamlı olarak korunduğu görülmektedir. Ayrıca TUNEL pozitif ve kazpaz-3 pozitif hücreler B3 grubuna ait kesitlerde oldukça az görülmüştür. Dialil disülfitin akut kadmiyum alımına karşı spermatogenez süreci üzerindeki olumsuz etkiyi kompanse ettiğini düşündürmüştür.

Bu bulgular, yaygın olarak tüketilen sarımsakta bulunan bir antioksidan olan dialil disülfitin, testiste ağır metal toksisitesine karşı yararlı koruyucu bir ajan olabileceğini düşündürmektedir.

B1 grubu ile B4 grubu Modifiye Johnsen skorlama sonuçları karşılaştırıldığında B4 grubu skorlama sonucunda anlamlı artış $(p<0,001)$ olduğu görülmektedir. Bu durum B4 grubunda akut kadmiyum maruziyetine karşı resveratrol ve dialil disülfitnin birlikte testiküler histomorfolojiyi ve spermatogenizi koruduğunu düşündürmüştür.

Yine Resveratrol ve dialil disülfitin birlikte uygulandığı 
B4 grubunda akut kadmiyum maruziyetine karşı bu iki bileşiğin birlikte kadmiyum kaynaklı apoptozu engellediği elde eldilen bulgularla ortaya konulmuştur. B1 grubu ile B4 grubu apoptotik indeks sonuçları karşılaştırıldığında B4 grubunda apoptotik indeks anlamlı olarak azalmıştır $(p<0,001)$. Bu durumda resveratrol ve dialil disülfit kombinasyonunun kadmiyum kaynaklı apoptozu önlediği söylenebilir.

Dialil disülfit, spermatogenezi koruduğu gibi kadmiyum kaynaklı apoptozu da önlemiştir. Bu koruyucu etkilerin altında yatan mekanizmaları daha iyi aydınlatmak için daha ileri çalışmalara intiyaç olmakla birlikte, dialil disülfit, ağır metal toksisitesinden kaynaklanan erkek infertilitesine karşı umut verici bir protektif ajan olabilir.

Sonuç olarak; çalışmamızda sıçan testisinde kadmiyum ile oluşturulan akut hasarın baskılanmasında resveratrol ve dialil disülfitin rolüne yönelik bilgiler ortaya konmuştur. Belirlediğimiz dozda resveratrol bu akut hasarın baskılanmasında etkili olmazken dialil disülfitin resveratrol ile birlikte kullanımı hasarı önlemede etkili bulunmuştur.

\section{Teşekkür}

Bu çalışma Uludağ Üniversitesi Bilimsel Araştırma Projeleri Birimi (KUAP(T)-2015/45 no'lu proje) tarafından desteklenmiştir.

\section{Kaynaklar}

1. ATSDR. Toxicological profile for cadmium. J Public Heal. Agency for Toxic Substances and Disease Registry (US), 2012;1487.

2. WHO. Air quality guidelines for Europe. Environmental Science and Pollution Research. 2nd edition. WHO Regional Publications, Copenhagen, 2000;pp:136-139.

3. Waalkes MP. Cadmium carcinogenesis. Mutation Research/ Fundamental and Molecular Mechanisms of Mutagenesis, 2003;533: 107-120.

4. Kara $\mathrm{H}$, Karataş $\mathrm{F}$, Canatan $\mathrm{H}$. Effect of single dose cadmium chloride administration on oxidative stress in male and female rats. Turkısh J Veterınary Anımal Scıences. 2005;29:37-42.

5. Koca N, Karadeniz F. Gıdalardaki doğal antioksidan bileşikler Gıda Derg. 2005;30(4):229-36.

6. Lee KM, Lee IC, Kim SH ve ark. Melatonin attenuates doxorubicin-induced testicular toxicity in rats. Andrologia. 2012;44:796803.

7. Sergides C, Chirilă M, Silvestro L, Pitta D, Pittas A. Bioavailability and safety study of resveratrol $500 \mathrm{mg}$ tablets in healthy male and female volunteers. Exp Ther Med. 2016;11(1):16470.

8. Aires V, Limagne E, Cotte AK, Latruffe N, Ghiringhelli F, Delmas D. Resveratrol metabolites inhibit human metastatic colon cancer cells progression and synergize with chemotherapeutic drugs to induce cell death. Mol Nutr Food Res. 2013;57(7):117081.

9. Bishayee A, Darvesh AS, Politis T, McGory R. Resveratrol and liver disease: Frombench to bedside and community. Liver Int. 2010;30(8):1103-14.
10. Kim SH, Lee IC, Baek H-S, Moon C, Kim S-H, Kim J-C. Protective effect of diallyl disulfide on cyclophosphamide-induced testicular toxicity in rats. Lab Anim Res 2013;29(4):204-11.

11. Fukao T, Hosono T, Misawa S, Seki T, Ariga T. The effects of allyl sulfides on the induction of phase II detoxification enzymes and liver injury by carbon tetrachloride. Food Chem Toxicol. 2004;42(5):743-9.

12. Guyonnet D, Belloir C, Suschetet M, Siess M-H, Le Bon A-M. Mechanisms of protection against aflatoxin B1 genotoxicity in rats treated by organosulfur compounds from garlic. Carcinogenesis. 2002;23(8):1335-41.

13. Nakagawa H, Tsuta K, Kiuchi K ve ark. Growth inhibitory effects of diallyl disulfide on human breast cancer cell lines. Carcinogenesis. 2001;22(6):891-7.

14. Pedraza-Chaverrí J, González-Orozco AE, Maldonado PD, Barrera D, Medina-Campos ON, Hernández-Pando R. Diallyl disulfide ameliorates gentamicin-induced oxidative stress and nephropathy in rats. Eur J Pharmacol. 2003;473(1):71-8.

15. Pari L, Murugavel P, Sitasawad SL, Kumar KS. Cytoprotective and antioxidant role of diallyl tetrasulfide on cadmium induced renal injury: An in vivo and in vitro study. Life Sci. 2007;80(7):650-8

16. Palsamy P, Subramanian S. Resveratrol protects diabetic kidney by attenuating hyperglycemia-mediated oxidative stress and renal inflammatory cytokines via Nrf2-Keap1 signaling. Biochim Biophys Acta - Mol Basis Dis. 2011;1812(7):719-31.

17. Di C, Han L, Zhang H ve ark. Diallyl disulfide attenuated carbon ion irradiation-induced apoptosis in mouse testis through changing the ratio of Tap73/ $\Delta$ Np73 via mitochondrial pathway. Nat Publ Gr. Nature Publishing Group; 2015;86(931):1-11.

18. Erdemir F, Atilgan D, Markoc F, Boztepe O, Suha-Parlaktas B, Sahin S. The effect of diet induced obesity on testicular tissue and serum oxidative stress parameters. Actas Urol españolas. 2012;36(3):153-9.

19. Odacı E, Hancı H, Yuluğ E ve ark. Effects of prenatal exposure to a $900 \mathrm{MHz}$ electromagnetic field on 60-day-old rat testis and epididymal sperm quality. Biotech Histochem. 2016;91(1):9-19.

20. Damek-Poprawa M, Sawicka-Kapusta K. Histopathological changes in the liver, kidneys, and testes of bank voles environmentally exposed to heavy metal emissions from the steelworks and zinc smelter in Poland. Environ Res. 2004;96(1):72-8.

21. Klaassen CD, Liu J, Diwan BA. Metallothionein Protection of Cadmium Toxicity. Toxicol Appl Pharmacol. 2009;238(3):21520.

22. Siu ER, Mruk DD, Porto CS, Cheng CY. Cadmium-induced testicular injury. Toxicology and Applied Pharmacology. 2010;238:240-9.

23. De Souza Predes F, Diamante MAS, Dolder H. Testis response to low doses of cadmium in Wistar rats. Int J Exp Pathol. 2010;91(2):125-31.

24. Herranz LM, Teba F, Martín R ve ark. Quantitative changes in rat seminiferous epithelium after chronic administration of low doses of cadmium and zinc: A Stereological Study. The Open Andrology Journal. 2010;27-36.

25. Othman MS, Nada A, Zaki HS, Abdel Moneim AE. Effect of Physalis peruviana $\mathrm{L}$. on cadmium-induced testicular toxicity in rats. Biol Trace Elem Res. 2014;159(1-3):278-87.

26. Kerr JB. Spontaneous degeneration of germ cells in normal rat testis: assessment of cell types and frequency during the spermatogenic cycle. J Reprod Fertil. 1992;95(3):825-30.

27. Athar M, Back JH, Tang $X$ ve ark. Resveratrol: a review of pre-clinical studies for human cancer prevention. Toxicol Appl Pharmacol. 2007;224(3):274-83.

28. Olas B, Nowak P, Kolodziejczyk J, Ponczek M, Wachowicz B. Protective effects of resveratrol against oxidative/nitrative modifications of plasma proteins and lipids exposed to peroxynitrite. J Nutr Biochem. 2006;17(2):96-102.

29. Patel KR, Brown VA, Jones DJL ve ark. Clinical pharmacology of resveratrol and its metabolites in colorectal cancer patients. 
Cancer Res. 2010;70(19):7392-9.

30. Hoshino J, Park E-J, Kondratyuk TP ve ark. Selective synthesis and biological evaluation of sulfate- conjugated resveratrol metabolites. J Med Chem. 2011;53(13):5033-43.

31. Bowers JL, Tyulmenkov V V, Jernigan SC, Klinge CM. Resveratrol acts as a mixed agonist/antagonist for estrogen receptors alfa and beta. Endocrinology. 2000;141(10):3657-67.

32. Wallerath T, Deckert G, Ternes T ve ark. Resveratrol, a polyphenolic phytoalexin present in red wine, enhances expression and activity of endothelial nitric oxide synthase. Circulation. 2002;106(13):1652-8.

33. Chen CK, Pace-Asciak CR. Vasorelaxing activity of resveratrol and quercetin in isolated rat aorta. Gen Pharmacol. 1996;27(2):363-6.

34. Orallo F, Alvarez E, Camiña M, Leiro JM, Gómez E, Fernández $\mathrm{P}$. The possible implication of trans-resveratrol in the cardioprotective effects of long-term moderate wine consumption. Mol Pharmacol. 2002;61(2):294-302.

35. Rakici O, Kiziltepe U, Coskun B, Aslamaci S, Akar F. Effects of resveratrol on vascular tone and endothelial function of human saphenous vein and internal mammary artery. Int J Cardiol. 2005;105(2):209-15.

36. Hussein MMA, Mahfouz MK. Effect of resveratrol and rosuvastatin on experimental diabetic nephropathy in rats. Biomed Pharmacother. 2016;82:685-92.

37. Li E, Guo Y, Wang G, Chen F, Li Q. Effect of resveratrol on restoring spermatogenesis in experimental cryptorchid mice and analysis of related differentially expressed proteins. Cell Biol Int. 2015;39(6):733-40.

38. Palsamy P, Sivakumar S, Subramanian S. Resveratrol attenuates hyperglycemia-mediated oxidative stress, proinflammatory cytokines and protects hepatocytes ultrastructure in streptozotocin-nicotinamide-induced experimental diabetic rats. Chem Biol Interact. 2010;186(2):200-10.

39. Silan C. The effects of chronic resveratrol treatment on vascular responsiveness of streptozotocin-induced diabetic rats. Biol Pharm Bull. 2008;31(5):897-902.

40. Ranawat $P$, Khanduja KL, Pathak $\mathrm{CM}$. Resveratrol - an ingredient of red wine abrogates the reproductive capacity in male mice. Andrologia. 2014;46(6):650-8.

41. Gehm BD, Mcandrews JM, Chien P-Y, Jameson JL. Resveratrol, a polyphenolic compound found in grapes and wine, is an agonist for the estrogen receptor. Physiology. 1997;94:1413843.

42. Lu R, Serrero G. Resveratrol, a natural product derived from grape, exhibits antiestrogenic activity and inhibits the growth of human breast cancer cells. Journal of Cellular Physiology. 1999; 179:297-304.

43. Svechnikov K, Izzo G, Landreh L, Weisser J, Sder O. Endocrine disruptors and leydig cell function. Journal of Biomedicine and Biotechnology. 2010;2010:10 pages.

44. Takiguchi M, Yoshihara S. New aspects of cadmium as endocrine disruptor. Environ Sci. 2006;13(2):107-16.

45. Le Corre L, Chalabi N, Delort L, Bignon Y-J, Bernard-Gallon DJ. Resveratrol and breast cancer chemoprevention: molecular mechanisms. Mol Nutr Food Res. 2005;49(5):462-71.

46. Siu ER, Wong EWP, Mruk DD, Sze KL, Porto CS, Cheng CY. An occludin-focal adhesion kinase protein complex at the blood-testis barrier: A study using the cadmium model. Endocrinology. 2009;150(7):3336-44.

47. Chung NPY, Cheng CY. Is cadmium chloride-induced inter-Sertoli tight junction permeability barrier disruption a suitable in vitro model to study the events of junction disassembly during spermatogenesis in the rat testis? Endocrinology. 2001;142(5):1878-88.

48. Lee IC, Baek HS, Kim SH ve ark. Effect of diallyl disulfide on acute gastric mucosal damage induced by alcohol in rats. Hum Exp Toxicol. 2014;1-13. 